deficient children and epileptics are not included in these statistics. It is noteworthy that in 1845, as far as figures are available, there seem to have been only 600 mental patients in Switzerland, equivalent to 0.2 per cent. of the population, but neither the figures nor the diagnoses can be worth much.

\section{ROYAL COLLEGE OF SURGEONS OF ENGLAND MUSEUM DEMONSTRATIONS.}

A SERIES of demonstrations of specimens in the Museum of the Royal College of Surgeons of England will shortly be given. The demonstrations are intended for advanced students and medical practitioners, and will take place in the theatre of the College in Lincoln's Inn-fields. The dates and subjects of the demonstrations are as follows: Friday, Oct. 16th, Professor Arthur Keith, Spècimens illustrating Gunshot Injuries of the HeadAncient and Modern. Monday, Oct. 19th, Mr. S. G. Shattock, Specimens illustrating Carcinoma. Wednesday, Oct. 21st, Mr. J. F. Colyer, Specimens of Injuries to the Jaws and Teeth of Animals. Friday, Oct. 23rd, Professor Keith, Specimens illus. trating Gunshot Injuries of the Limbs. Monday, Oct. 26th, Mr. Shattock, Specimens illustrating Tubercu) 3sis. Wednesday, Oct. 28th, Mr. Colyer, Specim is of Dento-alveolar Abscess and Dental Cyst. riday, Oct. 30th, Professor Keith, Gunshot Injuries of the Thorax and Abdomen. Monday, Nov. 2nd, Mr. Shattock, Specimens illustrating Repair. Professor Keith and Mr. Shattock will demonstrate at 5 P.M. each day and Mr. Colyer at 5.30 P.M.

\section{TESTICLE TRANSPLANTATION FROM THE DEAD} TO LIVING BODY.

A Most striking therapeutic procedure which apparently has met with remarkable success is reported in the New York Medical Journal (1914, c., 67) by Dr. G. Frank Lydston. It consisted, briefly, in the transplantation of a testicle from a man who had recently died into the scrotum of a second individual. The object of this proceeding was to try to effect relief for extensive psoriasis; the result was certainly beneficial. The writer is of opinion "that perversion of nutrition, primarily due, perhaps, to an aberration of quality and quantity of internal secretion-of the sex or other glands - underlay skin lesions of the class in question." His ideas, as foreshadowed in this paper, also extend to advocating the value of gland implantation to other conditions, such as diabetes, tuberculosis, and even carcinoma. The immediate case referred to here is that of a man aged 53, a hard drinker and gourmand; no syphilis; a history of two tappings for ascites six years previously, when he was supposed to have cirrhosis of the liver. His present condition showed a large and hard liver, and much ascites which was successfully tapped and six gallons of fluid removed. There was present also some evidence of a tumour mass in the abdomen. As regards the psoriasis, it extended on the back of the arms and forearms, the front of the right leg, the buttocks, the lumbar region, and the back. The patches were large and the patient had had them for many years. The operation consisted in the transplantation of a testicle-with the epididymis excised-removed from an apparently healthy subject about 21 years of age, dead 30 hours before from contact with a live wire. Operation was performed 10 hours after removal of the testis-that is, 40 hours after death. The post-operative course was uneventful. On the third day after the implantation improvement was noted in the psoriasis, and eight days after the operation the lesions were so improved that they could scarcely be recognised as psoriasis. Betterment of the general condition of the patient also followed, though there was some evidence of a further accumulation of fluid.

Tне National Health Insurance Commission have issued a Memorandum to Insurance Committees on the terms and conditions of medical service for next year, altering the arrangements for medical certificates and the dates for the revision of doctors' and chemists' agreements.

\section{AMBULANCE WORK IN FRANCE.}

BY James Donelan, M.CH., M.B. R.U.I.

CheValier OF THE CROWN OF ITALY; SURGEON TO THE THROAT DEPARTMENT OF THE ITALIAN HOSPITAL, LONDON.

IN accordance with the invitation of the Editor of THE LANCET I send the following notes of such observations as I have had an opportunity of making during my recent visit to some of the ambulances in the western portion of the seat of war in France. I should like to point out most distinctly that the ambulances I visited or in which I did some surgical work were only those in relation to the French army. The only British soldiers I came into contact with were a small party who had lost their way, one of whom had a bullet wound in the scalp, and some of our Army Service Corps who brought a comrade to the ambulance of which I had temporary charge at Crépy-en-Valois. This man had fallen under a train, and his left forearm and arm were so crushed that I had to amputate near the shoulder. In view of the naturally great interest in the arrangement for our own wounded I have requested a surgical colleague now in France to visit the line of country through which they are being sent down.

Arrangements for Dealing with the Wounded.

Any consideration of the ambulance arrangements must keep in view three factors: the gigantic nature of the conflict, the unprecedentedly large numbers of wounded, and the small opportunities of picking up the more severe cases beyond the trenches unless a decided advance has been gained. To some extent German firing on Red Cross workers and flags of truce for collection of wounded has also prevented the immediate assistance hoped for in a war between civilised armies.

Though the large majority of those who reach such base hospitals as Dieppe have bullet wounds of soft parts from which they as a rule rapidly recover, there is a good number of cases of wounds of cavities which have taken a serious turn since their arrival. During my journey up in the first train taking back refugees from the districts immediately south of the Aisne we had a very long halt while strengthening a trestle bridge that had been placed instead of one destroyed by the retreating enemy. No less than five long trains full of wounded French and one British passed us. There must have been between five and six thousand in all. The vast

1 We hope to publish a report from the well-known surgeon here indicated, but the vagaries of the French mails forbid any promise.ED. L. 
majority could be seen sitting up; many were looking out of the windows and waved their hands to us. On the other hand, the impression must be guarded against that this represents anything like the real picture. Owing to the desperate character of most of the fighting, its continuance, and the fact that commanders have had to check the excessive zeal of the medical services in the interests of the rest of the army, I am assured that a man severely wounded, as by shell fire, in the early part of the day has a very poor chance of being picked up outside the trenches before evening unless some advance is made or some lull takes place in the firing. This accounts to a large extent for the comparatively slight character of the wounds of the majority of those who reach the base hospitals.

The method followed by both the British and the French armies is to send all cases that appear to be able to bear the journey from the field dressing stations as rapidly as possible to the large hospitals in Paris, Rouen, and other cities. Those who prove unable to bear the journey in the train are discharged on the way where there happens to be a hospital. At a station on the way to Crépy I was shown a building in which were the bodies of three French soldiers who had died in the train. The more severely injured are, as far as possible, sent by motor ambulances to the nearer collecting hospitals or even to Paris if it appears practicable.

\section{The Nature of the Injuries.}

A reference to some injuries I have seen may be of interest. Most of them were bullet wounds. The orifice of entry of the German bullet just admits an ordinary cedar pencil, and in soft parts that of exit is hardly larger. Where the missile has been deflected by bone or other dense tissue it may continue its course sideways, causing much destruction. Since my return my attention has been called to the remarks of Mr. Selous on this subject, and I am inclined to reconsider my view of the case at Crépy mentioned by me in last week's issue. It is quite possible that even a nonexpanding bullet deflected from its course may have caused the destruction of the right side of the face there described. Unless expanding bullets are actually found in relation to such wounds, in view of Mr. Selous's remarks their use must be regarded as not proven. I do not think the German authorities systematically issue dum-dums, though there is ground for believing that individual soldiers, or even small parties of them, may sometimes convert ordinary bullets into expanding ones by suitable filing. I was also shown some skiagrams in which bullets had extensively splintered long bones, finally lodging in the articulations of hip and shoulder. In one the opposite course was taken. Entering the front of the femur it had run down the hollow of the bone, finally lodging in the tibia. Another showed a shrapnell ball fixed between the tibia and the femur.

One patient was shot immediately below the left auditory meatus, the missile knocking out the opposite upper canine and bicuspid. When one thinks of the relations to its course it is remarkable that he was discharged convalescent on the fourteenth day. The more serious bullet wounds were those in which there was splintering of long bones, and injuries to head, chest, or abdomen. A German prisoner under my care had been shot from behind, it was said by his own officer, the bullet passing under the scalp and ploughing the right parietal bone for about an inch. The inner table did not appear to be injured and he did very well for about a week, but just before I left he had developed encephalitis.

As might be expected in an old agricultural country, tetanus is very rife. I should not like to mention the proportion in the cases $I$ saw as there were not sufficient to form a general estimate. The proportion is, I am assured, very high, especially in cases of shell wounds of the lower extremities. Antitetanic serum is extensively used, but, as might be expected, has little influence in developed cases, and its use as a prophylactic remains yet to be more conclusively established. I had another German patient who died from tetanus on the fifteenth or seventeenth day after being hit; he underwent amputation below the knee, and secondary amputation for spreading gangrene at mid-thigh. He was one of the German prisoners whom their own surgeon did not visit on the occasion when he came to report on the wounds of the British and French prisoners during the German occupation.

On the whole the general impression I received was that though surgeons were much needed a week or two ago in some of the stations near the front the arrangements on the whole were admirable, and everyone was doing his a $\mathrm{t}$ her duty with the utmost zeal and self-sacrifice. . эople whose ideas of war and ambulance work are derived from witnessing mock combats at Olympia and elsewhere should not be at all ready to criticise the real thing, when enacted on the most gigantic scale and under the most terrible circumstances in the history of the world.

\section{DIEPPE AS A MILITARY HOSPITAL BASE.}

By W. Knowsley Sibley, M.A., M.D. Cantab.

THE following notes founded on a recent visit to Dieppe may prove of interest to readers of THE LANCET at the present time.

The French military medical authorities have placed as many of their base hospitals on the sea coast as possible, the opinion being that the fresh air of the seaside, together with the comparative absence of flies and mosquitoes, puts the wounded under the most favourable circumstances for their recovery.

The delightful French watering place, Dieppeso well known to many English people who appreciate the beauties of the coast of Normandy, and usually so gay and full of life-has been completely transformed into one huge base hospital for the wounded soldiers, French, German, and a few English. The Casino, the College, and nearly all the large hotels no longer cater for the pleasures and luxuries of the rich, but are full of the wounded, and bear testimony to man's marvellous inventions for the destruction of the lives and limbs of his fellow creatures.

The French military surgeon in command of all the Government Hospitals in Dieppe is Major Doctor Gauillard, of Rouen, who is attached to the 12th Chasseurs, and I had the honour of accom. panying him round the largest of his hospitals on Sunday last.

The College and all the large hotels on the sea front, such as the Grand, the Métropole, the Paris, and the Beau Rivage, have been hurriedly transformed into hospitals, and contain between them some 1200 wounded, and many more are expected. 